\title{
$22: 35642722-35659318$
}

National Cancer Institute

\section{Source}

National Cancer Institute. 22:35642722-35659318. NCI Thesaurus. Code C42006.

Physical location of CSF2RB_Gene 